\title{
Efektivitas Model Auditory Intellectualy Repetition dalam Meningkatkan Kemampuan Pemahaman Konsep Matematis Siswa
}

\author{
Helma Mustika ${ }^{*}$, Beni Junedi², Krysna Mawarty ${ }^{3}$ \\ 1,3 STKIP Insan Madani Airmolek, Indonesia \\ 2Universitas Bina Bangsa Kota Serang Banten \\ *Corresponding Author
}

\begin{tabular}{l} 
Informasi Artikel \\
\hline Diterima Redaksi: 00 Februari 2021 \\
Revisi Akhir: 00 Maret 2021 \\
Diterbitkan Online: 00 Juni 2021 \\
Kata Kunci \\
\hline Model Pembelajaran \\
Auditory Intellectually Repetition \\
(AIR), \\
Pemahaman Konsep \\
Korespondensi \\
\hline E-mai : helmamustika@gmail.com
\end{tabular}

\section{A B S T R A C T}

\begin{abstract}
This research is motivated by the low ability of students to understand mathematical concepts. The Auditory Intellectually Repetition (AIR) learning model can be used as an innovative teaching solution in improving the ability to understand concepts because the Auditory Intellectually Repetition (AIR) learning model is a learning model that emphasizes three aspects, namely learning by listening, learning by thinking and repetition. This study aims to determine the effectiveness of the Auditory Intellectual Repetition (AIR) learning model in improving students' understanding of mathematical concepts. The design of this research is Pre Experimental with the form of research used is One Group Pretest Posttest Design. The sampling technique used is Simple Random Sampling. After the samples were taken randomly, class X IPA 2 was chosen as the experimental class. The instrument in this study was in the form of a student's mathematical concept understanding ability test. The data analysis technique in this study used N-Gain data and the Paired Sample T Test (t test). Based on the average N-Gain value, it can be concluded that the Auditory Intellectual Repetition (AIR) learning model is effective in improving students' mathematical concept understanding abilities.
\end{abstract} matematis siswa. Model pembelajaran Auditory Intelletually Repetition (AIR) dapat
dijadikan suatu solusi pengajaran yang inovatif dalam meningkatkan kemampuan
pemahaman konsep karena model pembelajaran Auditory Intellectually Repetition (AIR)
merupakan model pembelajaran yang menekankan tiga aspek, yaitu belajar dengan
mendengar, belajar dengan berfikir dan pengulangan. Penelitian ini bertujuan untuk
mengetahui model pembelajaran Auditory Intelletually Repetition (AIR) efektif dalam
meningkatkan kemampuan pemahaman konsep matematis siswa. Desain penelitian
ini adalah Pre Experimental dengan bentuk penelitian yang digunakan adalah One Group
Pretest-Posttest Design. Teknik pengambilan sampel yang digunakan adalah Simple Ran-
dom Sampling. Setelah sampel diambil secara acak, terpilih kelas X IPA 2 sebagai kelas
eksperimen. Instrument dalam penelitian ini berupa tes kemampuan pemahaman
konsep matematis siswa. Teknik analisis data dalam penelitian ini menggunakan data
N-Gain dan uji Paired Sample T Test (Uji t). Berdasarkan rata-rata nilai N-Gain dapat
disimpulkan bahwa model pembelajaran Auditory Intelletually Repetition (AIR) efektif
dalam meningkatkan kemampuan pemahaman konsep matematis siswa.

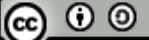

02021 by the authors. Submitted for possible open access publication under the terms and conditions of the Creative Commons Attribution-ShareAlike 4.0 International License-(CC-BY-SA) (https://creativecommons.org/licenses/by-sa/4.0/)

\section{Pendahuluan}

Matematika merupakan pelajaran yang memerlukan pemusatan pemikiran untuk mengingat dan mengenal kembali materi yang dipelajari sehingga siswa harus mampu menguasai konsep materi tersebut. Matematika tidak hanya memahami pelajaran secara sekilas tetapi harus juga memperhatikan kemampuan-kemampuan yang terdapat dalam pembelajaran matematika [2]. Salah satu kemampuan yang harus dimiliki siswa yaitu kemampuan pemahaman konsep. Dalam menguasai matematika, kepandaian siswa tidak hanya diukur dalam berhitung namun dilihat juga dari sisi bagaimana siswa tersebut dapat menyelesaikan permasalahan matematika yang diberikan. Salah satu kemampuan yang harus dimiliki siswa yaitu kemampuan pemahaman konsep. Dalam menguasai matematika, kepandaian siswa tidak hanya diukur dalam berhitung namun dilihat juga dari sisi bagaimana siswa tersebut dapat 
menyelesaikan permasalahan matematika yang diberikan. Pemahaman konsep merupakan salah satu aspek yang sangat penting dalam tercapainya tujuan mata pelajaran matematika.

Kenyataan dilapangan siswa hanya menghafal konsep dan kurang mampu menggunakan konsep tersebut jika menemui masalah yang merumuskannya. Menurut Lestari [3], kemampuan pemahaman konsep adalah kemampuan yang berkenaan dengan memahami ide-ide matematika yang menyeluruh dan fungsional. Dalam mempelajari mata pelajaran matematika perlu adanya penekanan konsep pada awal pembelajaran agar siswa dapat menyelesaikan soal-soal yang diberikan oleh guru dan dapat menggunakan serta menerapkan pembelajaran tersebut dalam kehidupan nyata. Faktanya salah satu penyebab kegagalan dalam pembelajaran matematika adalah siswa tidak paham konsep-konsep matematika atau siswa salah dalam memahami konsep-konsep matematika. Kesalahan konsep suatu pengetahuan saat disampaikan di salah satu jenjang pendidikan, bisa berakibat kesalahan pengertian dasar hingga ketingkat pendidikan yang lebih tinggi.

Menurut [14], pemahaman konsep matematis merupakan salah satu aspek kognitif yang bertujuan untuk menambahkan tingkat pengetahuan siswa terhadap materi pelajaran yang semula tidak tahu menjadi tahu dan yang semula tidak mengerti menjadi mengerti siswa terhadap materi pelajaran yang semula tidak tahu menjadi tahu dan yang semula tidak mengerti menjadi mengerti. Tujuan kognitif berupa kemampuan siswa dalam menguasai konsep matematika yang dapat dilihat dari nilai hasil tes yang diberikan, sedangkan aspek kognitif dilihat dari sikap dan aktivitas siswa saat pembelajaran berlangsung.

Pemahaman matematis diterjemahkan dari istilah mathematical understanding merupakan kemampuan matematis yang sangat penting dan harus dimiliki siswa dalam belajar matematika. Rasional pentingnya pemilikan kemampuan pemahaman matematis di antaranya adalah kemampuan tersebut tercantum dalam tujuan pembelajaran Kurikulum Matematika SM (KTSP 2006 dan Kurikulum 2013) dan dalam NCTM (1989). Tujuan mengajar matematika adalah agar pengetahuan yang disampaikan dapat dipahami peserta didik. Pentingnya pemilikan pemahaman oleh siswa dalam pemahaman konsep adalah aspek kunci dari pembelajaran. Depdiknas (2004) merinci kemampuan pemahaman sebagai berikut: (a) Menyatakan ulang sebuah konsep; (b) Mengklasifikasikan objek-objek menurut sifat-sifat tertentu sesuai dengan konsepnya; (c) Memberi contoh dan bukan contoh dari konsep; (d) Menyajikan konsep dalam berbagai bentuk representasi matematis; (e) Mengembangkan syarat perlu atau syarat cukup suatu konsep; (f) Menggunakan, memanfaatkan, dan memilih prosedur atau operasi tertentu; (g) Mengaplikasikan konsep atau algoritma dalam pemecahan masalah matematis.

Kemampuan pemahaman konsep adalah kemampuan yang berkenaan dengan memahami ide-ide matematika yang menyeluruh dan fungsional. Indikator pemahaman konsep matematis yaitu: (1) Menyatakan ulang konsep yang dipelajari; (2) Mengklasifikasikan objek-objek berdasarkan konsep matematika; (3) Menerapkan konsep secara algoritma; (4) Memberikan contoh atau kontra contoh dari konsep yang dipelajari; (5) Menyajikan konsep dalam berbagai representasi; (6) Mengaitkan berbagai konsep matematika secara internal atau eksternal. Untuk mencapai hal tersebut perlu digunakan model pembelajaran yang dapat meningkatkan pemahaman konsep matematis siswa.

Model pembelajaran adalah suatu pola interaksi antar siswa dan guru di dalam kelas yang terdiri dari strategi, pendekatan, metode, dan teknik pembelajaran yang diterapkan dalam pelaksanaan kegiatan pembelajaran di kelas [3]. Model pembelajaran adalah kerangka konseptual yang melukiskan prosedur yang sistematis dalam mengorganisasikan pengalaman belajar untuk mencapai tujuan belajar tertentu, dan berfungsi sebagai pedoman bagi para perancang pembelajaran dan para pengajar dalam merencanakan memberikan aktivitas belajar. 
Model pembelajaran adalah suatu perencanaan atau suatu pola yang digunakan sebagai pedoman dalam merencanakan pembelajaran di kelas atau pembelajaran dalam tutorial. Model pembelajaran mengacu pada pendekatan pembelajaran yang digunakan, termasuk di dalamnya tujuan-tujuan pembelajaran, tahap-tahap dalam kegiatan pembelajaran, lingkungan pembelajaran, dan pengelolaan kelas [5].

Model pembelajaran menurut [7], memiliki ciri-ciri: (1) Berdasarkan teori pendidikan dan teori belajar dari para ahli tertentu; (2) Mempunyai sisi atau tujuan pendidikan tertentu; (3)Dapat dijelaskan pedoman untuk perbaikan kegiatan belajar mengajar dikelas; (4) Memiliki bagian-bagian model yang dinamakan: urutan langkah-langkah pembelajaran, adanya prinsipprinsip reaksi, sistem sosial, sistem pendukung. Keempat bagian tersebut merupakan pedoman praktis bila guru melaksanakan suatu model pembelajaran, (5) Memiliki dampak sebagai akibat terapan model pembelajaran, (6) Membuat persiapan mengajar (desain intruksional) dengan pedoman model pembelajaran yang dipilihnya.

Salah satu model pembelajaran yang dapat digunakan dalam meningkatkan kemampuan pemahaman konsep yaitu model pembelajaran Auditory Intellectually Repetition (AIR). Model pembelajaran Auditory Intellectually Repetition (AIR) merupakan model pembelajaran yang menekankan tiga aspek, yaitu belajar dengan mendengar, belajar dengan berfikir dan pengulangan. Model pembelajaran ini baik digunakan dalam meningkatkan kerja sama kelompok, melatih siswa dalam berbagi pengetahuan dan membuat proses pembelajaran menjadi tidak membosankan [9]. Hasil penelitian (Hotmaida, dkk. 2020) menunjukkan bahwa kemampuan pemahaman konsep matematis siswa sebelum dan sesudah menggunakan model pembelajaran Auditory, Intellectualy, Repetition (AIR) mengalami peningkatan. Dalam penelitian [9] menunjukkan bahwa peningkatan kemampuan pemahaman konsep matematis siswa dengan penerapan model pembelajaran Auditory Intellectualy Repetition (AIR) lebih baik dari pada model pembelajaran biasa. Adapun kelebihan dari model Pembelajaran Auditory Intellectualy Repetition (AIR) menurut [11], yaitu (1) Siswa lebih berpartisi pasi aktif dalam pembelajaran dan sering mengekspresikan idenya. (2) Siswa memiliki kesempatan lebih banyak dalam memanfaatkan pengetahuan dan keterampilan secara komprehensif. (3) Siswa dengan kemampuan rendah dapat merespon permasalahan dengan cara mereka sendiri.

Berdasarkan hasil observasi yang peneliti lakukan di Madrasah Aliyah Khairul Ummah Batu Gajah (selanjutnya ditulis MA Khairul Ummah Batu Gajah) ditemukan beberapa permasalahan yaitu: Pertama, pemahaman konsep matematis siswa yang masih rendah. Ketika siswa sudah mampu manyatakan ulang konsep yang telah dipelajari, maka siswa tersebut telah memiliki bekal dasar untuk dapat mengerjakan soal-soal pemahaman matematika yang lainnya. Kedua, siswa kurang aktif dalam proses pembelajaran, ketika guru memberikan pertanyaan hanya beberapa siswa yang dominan dapat menjawab pertanyaan yang diberikan guru dan ada siswa yang belum mau bertanya ketika belum memahami materi pelajaran. Keempat, siswa cenderung kesulitan mengerjakan latihan jika permasalahan yang diberikan sedikit berbeda dengan contoh yang sudah dijelaskan.

Menurut Saimun (Wasiat, 2013) efektifitas dapat diartikan sebagai pencapaian suasana bagi manusia dalam mencapai tujuan pendidikan. Menurut Sutikno (2005), pembelajaran efektif merupakan suatu pembelajaran yang memungkinkan siswa untuk dapat belajar dengan mudah, menyenangkan, dan dapat mencapai tujuan sesuai dengan yang diharapkan. Efektivitas pembelajaran merupakan suatu ukuran keberhasilan dari proses interaksi dalam situasi edukatif untuk mencapai tujuan pembelajaran. Watkins et all (2007:19), mengemukakan bahwa efektivitas pembelajaran adalah suatu kegiatan yang membangun dengan ditangani oleh seseorang guru yang mendorong peserta didik melalui pendekatan dan strategi khusus untuk mencap mendorong peserta didik melalui pendekatan dan strategi khusus untuk mencapai 
tujuan pembelajaran dan prestasi siswa yang maksimal. Dari pengertian di atas, dapat disimpulkan bahwa efektivitas pembelajaran adalah tercapainya tujuan keberhasilan pembelajaran sesuai dengan target yang telah direncanakan.

Efektivitas pembelajaran merupakan salah satu standart mutu pendidikan dan sering kali diukur dengan tercapainya tujuan, atau dapat juga diartikan sebagai ketepatan dalam mengelola suatu situasi, "doing the right things". Menurut Supardi (2013) pembelajaran efektif adalah kombinasi yang tersusun meliputi manusiawi, material, fasilits, perlengakapan dan prosedur diarahkan untuk mengubah perilaku siswa ke arah yang positif dan lebih baik sesuai dengan potensi dan perbedaan yang yang dimiliki siswa untuk mencapai tujuan yang telah ditetapkan. Hamalik (2001) menyatakan bahwa pembelajaran yang efektif menyediakan kesempatan belajar sendiri dan beraktivitas seluas-luasnya diharapkan dapat membantu siswa dalam memahami konsep yang sedang di pelajari. Menurut [4], pembelajaran dikatakan efektif apabila tujuannya tercapai. Tujuan dalam pembelajaran matematika mencakup tujuan kognitif dan afektif. Tujuan kognitif berupa kemampuan siswa dalam menguasai konsep matematika yang dapat dilihat dari nilai hasil tes yang diberikan, sedangkan aspekkognitif dilihat dari sikap dan aktivitas siswa saat pembelajaran berlangsung. Pembelajaran dikatakan efektif jika memenuhi kriteria ketuntasan belajar perorangan dan klasikal. Seseorang siswa dikatakan tuntas belajar jika siswa tersebut telah mencapai skor KKM.

Jadi, dapat disimpulkan bahwa efektivitas pembelajaran adalah keberhasilan guru dan siswa dalam bentuk kepuasan untuk memperoleh dan memanfaatkan proses pembelajaran serta mencapai apa yang diharapkan bersama, sehingga dapat mengembangkan keterampilan dan kecerdasan siswa dalam proses mengajar. Indikator-indikator pengukuran efektivitas pembelajaran yaitu: (1) Hasil belajar; Pembelajaran dikatakan efektif jika memenuhi kriteria ketuntasan belajar perorangan dan klasikal. Seorang dikatakan tuntas belajar jika siswa tersebut telah mencapai skor KKM. (2) Aktivitas siswa ; Aktivitas siswa dalam pembelajaran bisa positif maupun negatif. Aktifitas yang positif misalnya: mengajukan pendapat atau gagasan, mengerjakan tugas atau soal, komunikasi dengan guru secara aktif dalam pembelajaran dan komunikasi dengan sesama siswa sehingga dapat memecahkan suatu permasalahan yang sedang dihadapi. Aktivitas negatif siswa misalnya: mengganggu sesama siswa pada saat proses belajar mengajar di kelas, melakukan kegiatan lain yang tidak sesuai dengan pelajaran yang sedang diajarkan guru. (3) Respon siswa; respon siswa adalah tanggapan orang-orang yang sedang belajar termasuk didalamnya mengenai pendekatan atau strategi, faktor yang mempengaruhi, serta potensi yang ingin dicapai dalam belajar. Dalam penelitian ini, indikaor efektivitas belajar yang digunakan adalah hasil belajar siswa dengan melihat nilai ketutasan siswa pada kemampuan pemahaman konsep.

Tujuan peneliti mengadakan penelitian adalah untuk mengetahui model pembelajaran Auditory Intellectually Repetition (AIR) efektif dalam meningkatkan kemampuan pemahaman konsep matematis siswa pada kelas X IPA MA Khairul Ummah Batu Gajah.

\section{Metode Penelitian}

Metode penelitian yang digunakan dalam penelitian ini adalah Pre Experimental dengan rancangan penelitian One Group Pretest Posttest Only Design dapat digambarkan pada tabel berikut:

Tabel 1. Bentuk desain one group pretest posttest design

\begin{tabular}{|ll}
\hline $\mathbf{O}_{1} \quad \mathrm{X} \quad \mathbf{O}_{2}$ \\
Sumber: Sugiyono, $2010: 75$
\end{tabular}


Penelitian ini dilaksanakan pada tahun ajaran 2020/2021. Populasi penelitian ini adalah siswa kelas X IPA yang berjumlah 58 siswa. Untuk menentukan sampel penulis menggunakan teknik pengambilan sampel Simple Random Sampling. Validitas suatu instrumen merupakan tingkat ketepatan suatu instrumen untuk mengukur sesuatu yang harus diukur. Suatu instrument yang valid atau sahih mempunyai validitas tinggi. Dari hasil perhitungan didapat bahwa rhitung $>r_{\text {tabel }}$ dengan $r_{\text {tabel }}=0,456$. Sehingga dapat disimpulkan bahwa soal nomor 1 sampai nomor 5 tersebut valid dan layak digunakan. Reliabilitas suatu instrumen adalah keajegan atau kekonsistenan instrumen tersebut bila diberikan pada subjek yang sama meskipun oleh orang yang berbeda, waktu yang berbeda, atau tempat yang berbeda, maka akan memberikan hasil yang sama atau relatif sama (tidak berbeda secara signifikan). Dari hasil analisis diperoleh bahwa nilai Croncbach's Alpha adalah 0,816. Dapat disimpulkan bahwa soal tes termasuk korelasi reliabilitas tinggi artinya soal dapat digunakan untuk penelitian berikutnya.

Daya pembeda dari suatu butir soal menyatakan seberapa jauh kemampuan butir soal tersebut membedakan antara siswa yang dapat menjawab soal dengan tepat dan siswa yang tidak dapat menjawab soal tersebut dengan tepat (siswa yang menjawab kurang tepat/ tidak tepat). Dari tabel 3.10 dapat dilihat bahwa soal nomor 1, 2, 4 dan 5 memiliki daya pembeda yang cukup dan soal nomor 3 memiliki daya pembeda yang baik. Indeks kesukaran adalah suatu bilangan yang menyatakan derajat kesukaran suatu butir soal. Dari tabel 3.12 dapat dilihat bahwa untuk soal 1, 2 dan 3 memiliki indeks kesukaran mudah. Soal nomor 4 memiliki indeks kesukaran sedang dan soal nomor 5 memiliki indeks kesukaran sukar. Berdasarkan hasil analisis statistik, bahwa 5 soal tersebut yaitu, memiliki tingkat reliabilitas tinggi, memiliki daya pembeda cukup dan baik, dan memiliki indeks kesukaran mudah, sedang dan sukar. Sehingga dapat disimpulkan bahwa 5 soal tersebut dapat digunakan.

Teknik analisis data yang digunakan pada penelitian ini adalah analisis data N-Gain dan analisis data statistik inferensial. Pengelolahan dan analisis data statistik inferensial dimaksudkan untuk menganalisis data dengan membuat generalisasi pada data sampel agar hasilnya dapat diberlakukan pada populasi. Data yang dianalisis berasal dari hasil tes kemampuan pemahaman konsep matematis siswa berupa skor. uji prasyarat yang digunakan adalah uji normalitas dan uji homogenitas. Selain itu, penelitian ini menggunakan uji hipotesis dengan uji-t dan uji data N-Gain. Untuk menghitung skor N-Gain dapat digunakan rumus berikut.

$$
N-\text { Gain }=\frac{\text { Skor Posttest }- \text { Skor Pretest }}{\text { SMI }- \text { Skor Pretest }}
$$

Tinggi atau rendahnya nilai N-Gain ditentukan berdasarkan kriteria berikut:

Tabel 2. Kriterian nilai n-gain

\begin{tabular}{|l|l|}
\hline Nilai N-Gain & Kriteria \\
\hline N-Gain $\geq 0,70$ & Tinggi \\
\hline $0,30<$ N-Gain $<0,70$ & Sedang \\
\hline N-Gain $\leq 0,70$ & Mudah \\
\hline
\end{tabular}

Pengujian hipotesis dilakukan secara statistik dengan menggunakan uji t. Dalam penelitian ini, pretest diberikan sebelum penerapan model pembelajaran Auditory Intellectually Repetition (AIR) dan Posttest diberikan setelah penerapan model pembelajaran Auditory Intellectually Repetition (AIR). Setelah dilaksanakan penelitian, data yang diperoleh akan dianalisis. 
.Tabel 3. Nilai rata-Rata Tes Awal (pretest) dan Tes Akhir (Posttest) Kemampuan Pemahaman Konsep Matematis Siswa

\begin{tabular}{cccccc}
\hline Desain & $\begin{array}{c}\text { Jumlah } \\
\text { Siswa } \\
(\mathbf{n})\end{array}$ & $\begin{array}{c}\text { Jumlah } \\
\text { Skor } \\
\left(\sum \boldsymbol{x}\right)\end{array}$ & $\begin{array}{c}\text { Nilai Ra- } \\
\text { ta-Rata } \\
(\bar{x})\end{array}$ & $\begin{array}{c}\text { Simpangan } \\
\text { Baku (s) }\end{array}$ & $\begin{array}{c}\text { Varians } \\
\left(\boldsymbol{s}^{2}\right)\end{array}$ \\
\hline Posttest & 20 & 1595 & 79,75 & 18,733 & 350,934 \\
Pretest & 20 & 1168 & 58,40 & 25,885 & 670,042 \\
\hline
\end{tabular}

Dari tabel 3 dapat dilihat bahwa terdapat perbedaan nilai rata-rata hasil tes akhir dan tes awal. Rata-rata tes akhir (Posttest) yaitu 79,75 lebih besar dari nilai rata-rata tes awal (pretest) yaitu 58,40. Simpangan baku pada tes akhir (posttest) yaitu 18,733 sedangkan pada tes awal (pretest) yaitu 25,885 dan varians pada tes akhir (posttest) yaitu 350,934 sedangkan pada tes awal (pretest) yaitu 670,042. Artinya semakin kecil simpangan baku dan varians maka data tidak menyebar dan menunjukkan data semakin baik.

Untuk lebih mempermudah dalam melihat perbedaan rata-rata kemampuan pemahaman konsep matematis siswa per butir soal maka akan disajikan pada gambar 1 berikut:

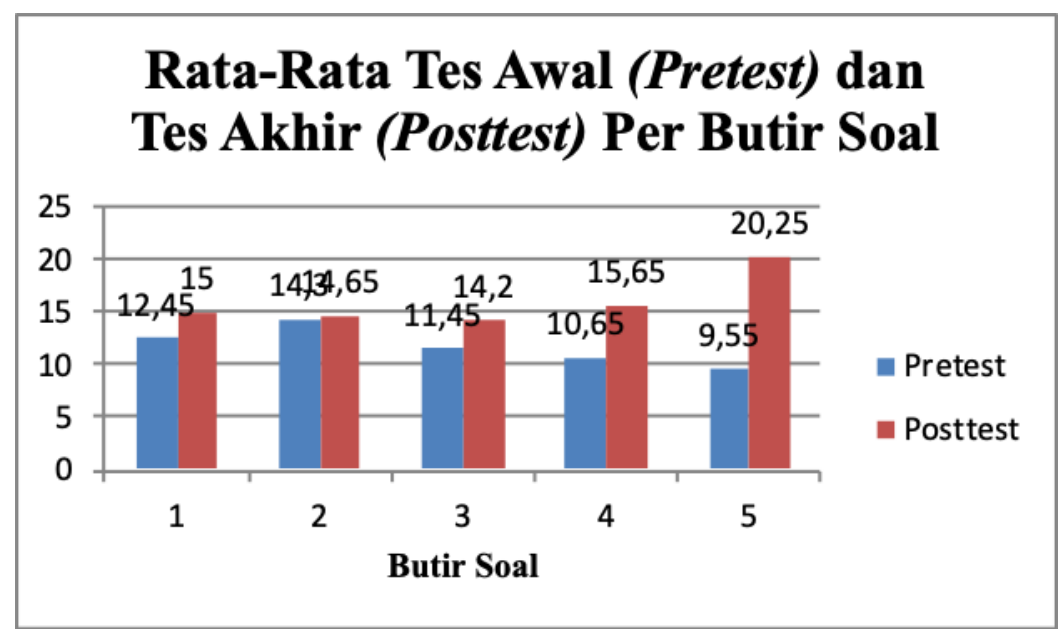

Gambar 1. Rata-rata hasil tes awal (pretest) dan tes akhir (posttest) pada setiap butir soal

Berdasarkan gambar 1 terlihat bahwa pada butir soal nomor 1 sampai nomor 5 memiliki rata-rata skor tes ahhir lebih tinggi dibandingkan rata-rata skor tes awal. Pada butir soal nomor 1 tes awal memiliki rata-rata 12,45 dan tes akhir memiliki rata-rata 15 . Pada butir soal nomor 2 tes awal memiliki rata-rata 14,3 dan tes akhir memiliki rata-rata 14,65. Pada butir soal nomor 3 tes awal memiliki rata-rata 11,45 dan tes akhir memiliki rata-rata 14,2. Pada butir soal nomor 4 tes awal memiliki rata-rata 10,65 dan tes akhir memiliki rata-rata 15,65. Pada butir soal nomor 5 tes awal memiliki rata-rata 9,55 dan tes akhir memiliki rata-rata 20,25. Berdasarkan perbandingan rata-rata skor tiap butir soal dapat disimpulkan bahwa nilai tes awal (Pretest) mengalami peningkatan setelah diberikan perlakuan model pembelajaran Auditory Intellectually Repetition (AIR).

Untuk menarik kesimpulan dari hasil penelitian yang dilakukan, maka data yang diperoleh dari tes kemampuan pemahaman konsep matematis siswa dilakukan dengan teknik analisis data berupa data N-Gain dan Uji Paired Sample T-Test. Data N-Gain digunakan untuk membandingkan selisih skor posttest dan pretest dengan selisih Skor Maksimum Ideal (SMI) dan Pretest. Uji Paired Sample T-Test digunakan untuk menjawab hipotesis penelitian 


\section{Hasil dan Pembahasan}

Berdasarkan hasil penelitian dengan menggunakan nomalitas gain, hasil analisis menunjukkan bahwa terdapat peningkatan nilai siswa pada hasil Posttest terhadap hasil Pretest. Untuk peningkatan pada kriteria tinggi sebanyak 3 siswa. Kriteria sedang sebanyak 6 siswa dan kriteria rendah sebanyak 11 siswa. Dengan nilai tertinggi yaitu 0,831 dan nilai terendah yaitu 1 . Berdasarkan hasil rata-rata niai N-Gain diperoleh nilai 0,575 yang termasuk pada kriteria sedang.

Uji normalitas dilakukan dengan menggunakan software SPSS. Uji normalitas dilakukan untuk melihat apakah kedua data berdistribusi normal atau tidak. Uji normalitas dilakukan pada nilai tes awal (pretest) dan tes akhir (posttest). Hasil perhitungan uji normalitas terlihat pada table 2 berikut:

Tabel 4. Hasil Perhitungan Uji Normalitas

\begin{tabular}{ccc}
\hline Design & Nilai Signifikan & Keterangan \\
\hline Pretest & 0,200 & Normal \\
Posttest & 0,192 & Normal \\
\hline
\end{tabular}

Dari tabel 4 terlihat bahwa nilai signifikan pada pretest adalah 0,200 dan nilai signifikan pada posttest adalah 0,193. Karena kedua nilai signifikan lebih besar dari 0,05, maka dapat disimpulkan bahwa kedua data berdistribusi normal. Uji homogenitas dilakukan untuk melihat apakah data memiliki variansi yang homogen. Nilai signifikan diperoleh adalah 0,098 pada uji homogenitas. Karena nilai signifikan lebih besar dari 0,05, maka data disimpulkan memiliki variansi yang homogen.

Setelah data berdistribusi normal dan memiliki variansi yang homogen maka dilanjutkan dengan uji hipotesis dengan menggunakan Uji Paired Sample T Test (Uji t). Berdasarkan hasil uji hipotesis diperoleh nilai sig. $<0,05$ yaitu $0,000<0,05$ maka keputusan yang diambil adalah terima $H_{1}$ dan tolak $H_{0}$. Jadi dapat disimpulkan bahwa "Model pembelajaran Auditory Intellectually Repetition (AIR) efektif dalam meningkatkan kemampuan pemahaman konsep matematis siswa"

Kemampuan pemahaman konsep matematis siswa pada hasil tes awal (pretest) dan hasil tes akhir (posttest), untuk masing-masing indikator, yaitu : 1).Menyatakan ulang konsep yang telah dipelajari, Kemampuan menyatakan ulang konsep yang telah dipelajari dapat ditinjau pada hasil tes siswa nomor 1 (Tentukan konsep aturan sinus dan aturan cosinus pada sebuah segitiga?), siswa diminta untuk menentukan aturan sinus dan aturan cosinus yang akan digunakan untuk menyelesaikan masalah.

Dari hasil tes awal (pretest), siswa belum mampu menyatakan ulang konsep yang telah dipelajari, hal ini ditunjukkan dengan jawaban siswa yang masih belum mamp menentukan aturan sinus sedangkan pada aturan cosinus siswa sudah mampu menentukan aturan cosinus, namun dalam menjawab aturan cosinus masih terdapat kesalahan dalam mencari sisi c. Pada jawaban hasil tes akhir (posttest), siswa sudah mampu menyatakan ulang konsep yang telah dipelajari. Hal tersebut dapat terlihat dengan jawaban siswa yang sudah mampu menyatakan aturan sinus dan aturan cosinus.

Pada indikator ke dua yaitu menyajikan konsep dalam berbagai representasi, menyajikan konsep berbagai representasi dapat ditinjau pada hasil tes siswa soal nomor 4, siswa diminta untuk dapat menentukan besar sudut yang ditanyakan (Tentukan besar sudut C!). Untuk dapat menentukan besar sudut yang ditanyakan di soal, maka siswa harus menentukan aturan sinus yang sesuai dengan permasalahan. Setelah menentukan aturan sinus dilanjutkan dengan memasukkan angka-angka yang sudah diketahui kedalam aturan sinus. Seperti yang tercantum dalam soal berikut: 


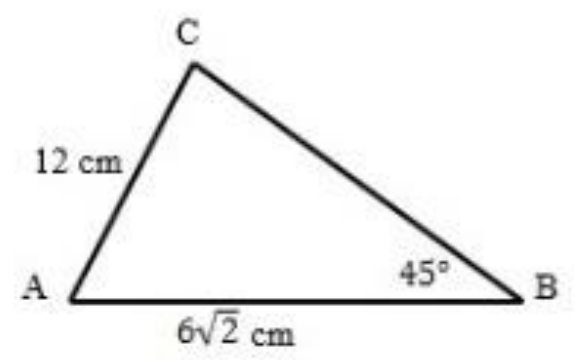

Gambar 2. Gambar Segitiga

Dari hasil tes awal (pretest), siswa sudah mampu menentukan aturan sinus dan memasukkan angka-angka yang sudah diketahui kedalam aturan sinus yang telah diketahui. Namun pada penyelesaian, siswa keliru ketika terdapat perkalian akar. Sehingga mengakibatkan hasil yang diperoleh tidak sesuaidengan yang diharapkan. Sedangkan jawaban hasil tes akhir (posttest), siswa sudah mampu menentukan aturan sinus yang akan digunakan dan memasukkan angkaangka yang sudah diketahui kedalam aturan sinus. Siswa sudah mampu menyelesaikan permasalahan dengan benar dan dapat menentukan besar sudut istimewa yang diminta.

Pada Indikator ke tiga menerapkan konsep secara algoritma, menerapkan konsep secara algoritma dapat ditinjau pada hasil tes siswa pada nomor 2,3 dan 5, pada soal nomor 2 (Sebuah segitiga $A B C$ dengan sudut $A=30^{\circ}$, sudut $B=45^{\circ}$ dan panjang $A C=10 \mathrm{~cm}$. Tentukan panjang sisi $B C$ !), siswa diminta untuk dapat menentukan panjang sisi BC. Untuk mendapatkan jawaban tersebut siswa harus menentukan terlebih dahulu aturan sinus yang akan digunakan. Setelah menentukan aturan sinus yang akan digunakan maka siswa memasukkan angka-angka yang telah ada disoal kedalam aturan sinus. Kemudian siswa dapat menyelesaikan permasalahan yang telah ada.

Dari hasil tes awal (pretest), siswa belum mampu memahami aturan sinus. Hal tesebut dapat dilihat dengan jawaban siswa yang hanya mampu menyatakan aturan sinus dan belum mampu untuk menyelesaikan permasalahan secara terurut. Sedangkan jawaban hasil tes akhir (posttest), siswa yang sudah mampu menggambarkan permasalahan yang akan diselesaikan. Kemudian siswa sudah mampu menyelesaikan permasalahan secara terurut, mulai dari menyatakan aturan sinus yang akan digunakan, menuliskan besaran sudut yang diinginkan serta siswa sudah mendapatkan hasil akhir yang diharapkan.

Pada soal nomor 3 (Sebuah segitiga $A B C$ diketahui panjang sisi $B C=8 \mathrm{~cm}$, panjang sisi $A B$ $=10 \mathrm{~cm}$ dan besar sudut $B=60^{\circ}$. Tentukan panjang sisi $\left.A C !\right)$, siswa diminta untuk dapat menentukan nilai AC. Untuk mendapatkan jawaban tersebut siswa harus menentukan terlebih dahulu aturan cosinus yang akan digunakan. Setelah menentukan aturan sinus yang akan digunakan maka siswa memasukkan angka-angka yang telah ada disoal kedalam aturan sinus. Kemudian siswa dapat menyelesaikan permasalahan yang telah ada.

Dari hasil tes awal (pretest), siswa sudah mampu menyatakan aturan cosinus yang digunakan, namun siswa belum mampu untuk menentukan apa yang tanyakan dalam soal. Hal ini terlihat siswa masih salah dalam memasukkan angka-angka yang sudah dituliskan disoal. Sedangkan jawaban hasil tes akhir (posttest), siswa sudah mampu menyelesaikan permasalahan secara terurut, mulai dari menyatakan aturan cosinus yang akan digunakan. Siswa juga sudah mampu mengingat besaran sudut istimewa serta siswa sudah mendapatkan hasil akhir yang diharapkan.

Pada soal nomor 5 (Dua buah kapal berangkat dari titik yang sama dengan membentuk sudut $60^{\circ}$. Jika kapal pertama bergerak dengan kecepatan $20 \mathrm{~km} / \mathrm{jam}$ dan kapal kedua bergerak dengan kecepatan $45 \mathrm{~km} / \mathrm{jam}$. Tentukan jarak kedua kapal berlayar selama 2 jam perjalanan!), siswa diminta untuk menentukan jarak kedua kapal berlayar. Untuk dapat menentukan jarak kedua kapal berlayar siswa harus terlebih dahulu mencari kecepatan kedua kapal tersebut. Setelah diketahui kecepatan kedua kapal maka dapat menentukan menggunakan aturan cosinus. Dengan demikian siswa akan diminta untuk mengingatserta mengaplikasikan konsep yang diperlukan dalam memecahkan masalah serta mengaplikasikan konsep yang diperlukan secara 
algoritma atau terurut sesuai langkah-langkah yang dibutuhkan untuk mendapatkan jawaban yang benar.

Dari hasil tes awal (pretest), siswa belum mampu menerapkan konsep secara algoritma. Hal tersebut dapat dilihat dengan jawaban siswa yang belum mampu menentukan aturan cosinus yang digunakan. Sedangkan jawaban hasil tes akhir (posttest), siswa sudah mampu menerapkan konsep secara algoritma. Hal ini terlihat siswa sudah mempu menyelesaikan permasalahan sesuai dengan langkah-langkah. Siswa sudah mampu menuliskan terlebih dahulu cara mendapatkan kecepatan kedua kapal setelah berjalan selama 2 jam. Kemudian siswa memasukkan angka yang telah didapatkan kedalam aturan cosinus sehingga siswa sudah mendapatkan hasil akhir yang diharapkan.

Berdasarkan hasil pembahasan atau penjabaran mengenai tes awal (pretest) dan tes akhir (posttest) kemampuan pemahaman konsep matematis siswa dari deskripsi indikator yang dipilih maka diperoleh hasil bahwa nilai rata-rata posttest dengan menggunakan model pembelajaran Auditory Inntellectually Repetition (AIR) mengalami peningkatan dibandingkan nilai rata-rata pretest.

\section{Kesimpulan}

Berdasarkan hasil penelitian yang dilakukan diperoleh hasil bahwa hasil rata-rata N-Gain yaitu 0,575 termasuk kategori sedang dan hasil uji hipotesis menyimpulkan model pembelajaran Auditory Intellectually Repetition (AIR) efektif dalam meningkatkan kemampuan pemahaman konsep matematis siswa.

\section{Daftar Pustaka}

[1] Makmur, Agus. (2015). "Efektifitas Penggunaan Metode Base Method dalam Meningkatkan Kreativitas dan Motivasi Belajar Matematika Siswa SMP N 10 Padang Sidimpuan”. Jurnal EduTech. 1, (1).

[2] Hadi, Sutarto Hadi dan Maidatani Umi Kasum.(2015). "Pemahaman Konsep Matematika Siswa SMP Melalui Penerapan Model Pembelajaran Kooperatif Tipe Memeriksa Berpasangan (Pair Checks)".Jurnal Pendidikan Matematika. 3, (1), 59-66

[3] Hendriana, Heris, dkk. 2017. Hard skills dan soft skills matematik siswa(Bandung : PT Refika Aditama)hal 3.

[4] Lestari, Karunia Eka dan Mokhammad Ridwan Yudhanegara. (2015).Penelitian Pendidikan Matematika. Bandung: PT Refika Aditama.

[5] Makmur, Agus. (2015). "Efektifitas Penggunaan Metode Base Method dalam Meningkatkan Kreativitas dan Motivasi Belajar Matematika Siswa SMP N 10 Padang sidimpuan".JurnalEduTech. 1, (1)

[6] Nurlaelah, N.,Sakkir.(2020). "Model Pembelajaran Respons Verbal dalam Kemampuan Berbicara".JurnalPendidikan. 4, (1), 113-122

[7] Ridwan, Rizky Ayu Fatimah. (2018).Efektivitas Penerapan Pendekatan SAVI Setting Cooperative Scrpt Dalam Pembelajaran Matematika Siswa Kelas IX SMP Negeri 33 Makassar. Skripsi Sarjana pada Fakultas Matematika dan Ilmu Pendidikan Pengetahuan Alam Universitas Negeri Makassar

[8] Rusman. 2011. Model-Model Pembelajaran. Jakarta : Rajawali Pers.

[9] Sarniah, Siti, dkk. (2019). "Pengaruh Model Pembelajaran Auditory Intellectualy Repetition (AIR) terhadap Kemampuan Pemahaman Konsep Matematis. Jurnal of Madives. 3, (1), halaman 94 
[10] Simamora. (2019). "Efektivitas Model Pembelajaran Audiotory Intellectualy Repetition (AIR) dengan Kemampuan Pemecahan Masalah Matematis Siswa di SMK Kesehatan Sidimpuan Husada”. Jurnal MatEdu. 2, (2), halaman 29.

[11] Siregar, HL, dkk. (2020). "Efektivitas Penggunaan Model Pembelajaran Audiotory, Intellectually, repetition (AIR) terhadap Pemahaman Konsep Matematika Siswa. Jurnal MathEdu. 3, (3), halaman 43

[12] Shoimin, Aris. 2014.68 Model Pembelajaran INOVATIF dalam Kurikulum 2013. Yogyakarta: AR-RUZZ MEDIA

[13] Trianto. (2015). Model Pembelajaran Terpadu. Jakarta: PT Bumi Aksara.

[14] Wijaya, dkk.(2018). "Kemampuan Pemahaman Matematis Siswa Menggunakan Model Pembelajaran Audiotory Intellectually. 